\title{
DESCRIÇÃO DOS FRUTOS NATIVOS UTILIZADOS NA ALIMENTAÇÃO DO POVO INDÍGENA RIKBAKTSA
}

\author{
Edson Utumy \\ Marcelo Franco Leão²
}

\section{RESUMO}

Com o intuito de registrar os conhecimentos tradicionais e científicos sobre a alimentação do povo indígena Rikbaktsa, este estudo tem como objetivo descrever as características básicas dos frutos nativos utilizados na alimentação dos Rikbaktsa e a maneira como ocorre esse consumo. Trata-se de um estudo etnográfico, desenvolvido no período de 2014 a 2016, que envolveu as três Terras Indígenas: Erikpatsa, Japuíra e Escondido, localizadas nos municípios mato-grossenses de Brasnorte, Juara, Cotriguaçu, respectivamente. Os dados foram coletados por meio de entrevistas com os anciãos de diferentes comunidades, além das observações a campo sobre os frutos comestíveis disponíveis na região. Os frutos foram desenhados e posteriormente descritos quanto à época de colheita e a maneira como são consumidos. $O$ estudo permitiu descrever 32 frutos nativos comestíveis do povo Rikbaktsa. Essa variedade encontrada pode estar relacionada ao fato de o território investigado comportar parte de cerrado, bem como possuir área de floresta amazônica. Foi possível identificar os nomes de cada fruto na língua materna, popular e científico e a sazonalidade desses frutos. Quanto à maneira de preparo, constatou-se que alguns deles servem para comer assim que retirado do pé, outros ficam guardados durante três ou mais dias a fim de amadurecer, outros são cozidos, outros servem para fazer suco ou chicha (bebida fermentada). 0 estudo permitiu registrar características dos frutos nativos é uma maneira de preservar a cultura e fortalecer os costumes para que não sejam esquecidos. Espera-se que esse artigo sirva como fonte de consulta às futuras gerações, indígenas e não indígenas.

Palavras-chave: Alimentação. Modo de consumo. Povo tradicional.

\footnotetext{
1 Graduação em Licenciatura em Ciências Matemáticas e da Natureza, ofertado pela Faculdade Intercultural Indígena (UNEMAT). Formação de Professores Indígenas para o Magistério Intercultural, Modalidade Normal em Nível Médio - Projeto Haiyô. Diretor da Escola Estadual Indígena de Educação Básica Pé de Mutum, localizada no município de Juara, Mato Grosso, Brasil. E-mail: edsonrikbakta@gmail.com

2 Doutorado em andamento Educação em Ciências (UFRGS). Mestre em Ensino (UNIVATES). Especialização em Orientação Educacional (Dom Alberto) e em Relações Raciais na Educação e na Sociedade Brasileira (UFMT). Graduação em Licenciatura em Química (UNISC) e em Física (UNEMAT). Professor do Departamento de Ensino do IFMT Campus Confresa, localizado no município de Confresa, Mato Grosso, Brasil. E-mail: marcelo.leao@cfs.ifmt.edu.br
} 


\title{
DESCRIPTION OF NATIVE FRUITS USED IN THE INDIGENOUS RIKBAKTSA PEOPLE'S
}

\section{DIET}

\begin{abstract}
With aims to registering traditional and scientific knowledge of the native Rikbaktsa people's diet, the purpose of this study is to describe the basic characteristics of the native fruits used by the Rikbaktsa peoples's diet and the manner in which they are consumed. It is an ethnographic study carried out between 2014 and 2016 involving three Indigenous Lands: Erikpatsa, Japuíra and Escondido, located in the Mato Grosso municipalities of Brasnorte, Juara, Cotriguaçu, respectively. The data were collected from interviews with the elderlies from different communities, as well as field observations of the edible fruits available in the region. The fruits were sketched and then the harvest time and the manner of consumption were described. Following the study, it was possible to describe 32 native edible fruits of the Rikbaktsa people. The finding of such a variety may be related to the fact that the territory being investigated covers a portion of cerrado and also features an area of the amazon forest. It was possible to investigate the names of each fruit in the native and popular languages, as well as scientific, and the seasonality of those fruits. Regarding the manner of preparation, it was found that some can be eaten immediately after being picked from the tree, others are stored for three or more days to ripen, others are cooked, others are used to prepare juices or chicha (fermented beverage). The study allowed for the recording of characteristics of native fruits and is a form of preserving the culture and strengthening the costumes lest they be forgotten. It is expected that this article serves as a source of consultation of future generations, both indigenous and non-indigenous.
\end{abstract}

Keywords: Diet. Native fruits. Manner of consumption. Traditional people.

\section{DESCRIPCIÓN DE LOS FRUTOS NATIVOS UTILIZADOS EN LA ALIMENTACIÓN DEL PUEBLO INDÍGENA RIKBAKTSA}

\section{RESUMEN}

Con el fin de registrar los conocimientos tradicionales y científicos sobre la alimentación del pueblo indígena Rikbaktsa, este estudio tiene como objetivo describir las características básicas de los frutos nativos utilizados como alimentos de los Rikbaktsa y la manera con que ocurre ese consumo. Tratase de un estudio etnográfico, desarrollado en el período de 2014 a 2016, que involucró las tres Tierras Indígenas: Erikpatsa, Japuíra y Escondido, ubicadas en los municipios matogrossenses de Brasnorte, Juara, Cotriguaçu, respectivamente. Los datos fueron recolectados por medio de entrevistas con los ancianos de diferentes comunidades, además de las observaciones al campo sobre los frutos comestibles disponibles en la región. Los frutos fueron dibujados y posteriormente descritos en cuanto a la época de cosecha y la manera que se consumen. El estudio permitió describir 32 frutos nativos comestibles del pueblo Rikbaktsa. Esta variedad encontrada puede estar relacionada al hecho de que el territorio investigado comporta parte de cerrado, así como existe área de selva amazónica. Fue posible 
identificar los nombres de cada fruto en la lengua materna, popular y científica y la estacionalidad de esos frutos. A respeto de la manera de preparación, se constató que algunos de ellos sirven para comer tan pronto como se retiran del pie, otros quedan guardados durante tres o más días para madurar, otros son cocidos, otros sirven para hacer jugo o chicha (bebida fermentada). El estudio permitió registrar características de los frutos nativos es una manera de preservar la cultura y fortalecer las costumbres para que no sean olvidadas. Se espera que este artículo sirva como fuente de consulta a las futuras generaciones, indígenas y no indígenas.

Palabras clave: Alimentación. Modo de consumo. Pueblo tradicional.

\section{INTRODUÇÃO}

Muito antes da chegada dos colonizadores portugueses ao Brasil, os povos indígenas já habitavam o local e se organizavam em determinados territórios. No estado de Mato Grosso, não diferente de outras localidades brasileiras, esses povos tradicionais se estabeleceram desde tempos imemoriais e suas contribuições referentes à maneira de viver e se relacionar com a natureza poderiam trazer benefícios para o restante do povo brasileiro, desde que ocorresse socialização, compreensão e o respeito ao modo de vida do outro (CREPALDI, 2012).

Segundo dados da Fundação Nacional do Índio (FUNAI), a população indígena estimada em Mato Grosso é de 25.123 pessoas aproximadamente, que estão distribuídas em 42 etnias (FUNAl, 2010). Esses povos tradicionais constituíram organizações sociais com culturas próprias e, consequentemente, com diferentes costumes, regras e formas de viver.

Uma importante característica a ser considerada é que a cultura indígena é rica em tradições e costumes, dentre os quais se destacam a forma de organização social, a alimentação, a relação próxima e harmoniosa com a natureza, os mitos e rituais, além dos costumes e tradições ensinados de geração em geração (PEREIRA, 1994). Contudo, Crepaldi (2012) salienta que a cultura indígena não é estática, ou seja, assim como qualquer outra ela é dinâmica e sofre constantes transformações, principalmente por coexistir com outras culturas envolventes.

Essas mudanças socioculturais e econômicas se intensificam nas últimas décadas, na medida em que o contato com o não indígena se 
estabeleceu. Prova disso é que muitas comunidades tradicionais matogrossenses já abandonaram sua forma de alimentação, bem mais saudável, em detrimento da alimentação industrializada do não índio.

Em seus estudos, Crepaldi (2012) afirma que os conhecimentos tradicionais a respeito das práticas alimentares são ensinados de geração para geração, que na maioria das vezes, é um processo exercido pelas mulheres mais experientes. Aliás, entre os povos indígenas o hábito de ensinar é reservado às pessoas mais velhas.

No entanto, ainda segundo a autora supracitada, com o passar do tempo, os saberes tradicionais estão sendo esquecidos por não possuírem registros, nem estudos, o que permitiria sistematizar e consequentemente perpetuar esses conhecimentos. Diante dessa problemática, a autora sugere que se desenvolvam estudos nas comunidades tradicionais, que sejam registrados e sistematizados os saberes das pessoas mais experientes sobre a cultura local, o que pode vir a fortalecer os costumes e tradições desse povo e servir de subsídios educativos para as próprias escolas das comunidades.

Outro aspecto a ser considerado é que a educação indígena ocorre no cotidiano e envolve os aspectos da cultura, em que o convívio com os outros proporciona aprendizados recíprocos. Segundo Maturana (1997), o processo educativo perpassa pela história de convivência e se constrói tendo como parâmetro a maneira de proceder daqueles com quem convive.

Dessa forma, o presente estudo é referente à descrição dos frutos nativos e o modo de consumo na alimentação do povo indígena Rikbaktsa. Trata-se de um recorte do Trabalho de Conclusão de Curso de Licenciatura em Ciências Matemáticas e da Natureza, apresentado para a Faculdade Intercultural Indígena da Universidade do Estado de Mato Grosso (UNEMAT), cuja defesa ocorreu no ano de 2016.

Essa pesquisa sobre os frutos nativos consumidos pelo povo Rikbaktsa teve motivações relevantes, dentre as quais serão pontuadas as mais significativas. Uma delas é o desconhecimento dos jovens dessa comunidade tradicional, quanto aos frutos que consomem e também 
quanto aos seus nomes na língua materna. Por outro lado, não se conhece o nome popular de muitas dessas frutas na língua portuguesa, mas sim na língua Rikbaktsa, o que também será muito útil para ser trabalhado em sala de aula ao ensinar ciências naturais.

Também cabe aqui mencionar que um dos pesquisadores é indígena, pertencente a essa etnia, e desde 2005 atua na Escola Estadual Indígena de Educação Básica Pé de Mutum. A escolha por esse tema é devido considerá-lo de suma importância tanto para o fortalecimento da cultura do povo Rikbaktsa, quanto para a formação escolar por envolver também aspectos científicos.

Outra motivação está relacionada ao fato do interesse pessoal do pesquisador em investigar e registrar um pouco de cada um dos frutos, dos lugares que são encontrados, da época de colheita e do modo como esses frutos são consumidos. Além disso, os frutos nativos sempre foram utilizados na alimentação dos povos indígenas.

Conforme Vieira et al. (2006) discutem, essas frutas são fundamentais na alimentação devido à quantidade de vitaminas e sais minerais que oferecem à saúde humana. De acordo com Gonçalves, Duarte e Tsukamoto Filho (2015), a região centro-oeste é rica em espécies de frutos nativos, muitos deles são comestíveis e de boa qualidade. Essa característica de grande diversidade de espécies vegetais é possível devido aos biomas presentes, dentre os quais se destacam o cerrado e a floresta amazônica em Mato Grosso, mais especificamente no local de desenvolvimento da investigação.

Diante do exposto, este estudo teve como objetivo principsl o resgate dos conhecimentos tradicionais do povo Rikbaktsa sobre os frutos nativos utilizados em nossa alimentação, por meio da descrição de suas características, sazonalidade, colheita e preparo para o consumo.

Dessa maneira, espera-se que essa coletânea dos frutos nativos consumidos por esse povo tradicional servirá como uma fonte de pesquisa para professores e estudantes indígenas, bem como a outros pesquisadores que possam se interessar. Ou seja, acredita-se que esse estudo poderá servir 
para ser explorado em aulas de ciências naturais tanto em escolas indígenas quanto nas não indígenas.

\section{CARACTERIZAÇÃO DO POVO RIKBAKTSA}

Os Rikbaktsa vivem na bacia do rio Juruena, mais especificamente na região noroeste do estado de Mato Grosso. Por habitarem uma região onde viviam outros grupos tupis, pelas descrições que faziam seringueiros e povos vizinhos, e por aspectos culturais e semelhanças linguísticas, acreditava-se que os Rikbaktsa eram um povo de língua Tupi (ARRUDA, 1992). Contudo, verificou-se que esse povo tradicional é falante da língua Rikbaktsa, filiada ao tronco linguístico Macro-Jê (REIS; FRANÇA, 2013).

Essa população vive na região sudoeste amazônica do Estado de Mato Grosso. A localização mais precisa desse povo tradicional é descrita por Reis e França (2013, p. 7), da seguinte maneira:

\footnotetext{
O povo Rikbaktsa imemorialmente vive na bacia do rio Juruena e seu território tradicional situava-se entre os paralelos $9^{\circ}$ e $12^{\circ}$ graus de latitude sul e os meridianos $57^{\circ}$ e $59^{\circ}$ graus de longitude oeste, espraiando-se pela bacia do rio Jurvena, desde a barra do rio Papagaio, ao sul, até quase o Salto Augusto no alto Tapajós, ao norte, hoje conhecido como Parque Estadual Igarapés do Jurvena; a oeste expandia-se em direção ao rio Aripuanã e a leste até o rio Arinos, na altura do rio dos Peixes, configurando uma região de cerca de 50 mil km².
}

A região que abrigava esse povo tradicional pode ser considerada isolada, no que se refere ao contato com os centros urbanos e até mesmo, no passado, com os não indíos. Isso pode estar atrelado ao fato de que essa localização não estava na rota de travessia das expedições ocorridas desde o século XVII. Em seus estudos, Arruda (2014) alega que nunca ocorreu, ou ao menos não se tem registro, do contato dos Rikbaktsa com os não indígenas antes do século XX, nem mesmo com as embarcações que por ventura circulassem ao longo dos rios da região.

Essa teoria também é defendida por Reis e França (2013) que acreditavam não ser hábito dos Rikbaktsa frequentar as margens dos grandes rios, principalmente na época de chuvas, pois era justamente quando os rios transbordavam e isso facilitava a navegação dos não 
indígenas e dificultava a chegada dos indígenas às margens dos rios. Ou seja, era pequena a possibilidade de contato.

Mesmo esse território sendo atravessado pelos não indígenas desde o século XVIII, por meio de expedições comerciais e científicas que se limitavam às proximidades de seus principais rios, nada se conhecia do interior desta região. Isso se deve ao fato de serem frequentemente atacados pelos índios tidos como bravos e desconhecidos (ARRUDA, 2014).

A partir de 1942, novos incentivos relacionados à extração da borracha e a instalação da Cia Colonizadora Noroeste Mato-Grossense Ltda (CONOMALI) deu-se o contato deste povo com a sociedade nacional dos não indígenas após anos de resistência guerreira (ISA, 2016).

O primeiro contato pacífico que se tem registro entre a frente colonizadora com os Rikbaktsa aconteceu em 30 de julho de 1957, dando início ao processo de atração desses indígenas provocando, assim, o fim de sua resistência armada e garantindo a ocupação das terras aos seringalistas (ARRUDA, 1992).

Diante dos conflitos armados e dos ataques de epidemias de gripe, sarampo, varíola e doenças venéreas, o povo Rikbaktsa sofreu uma baixa significativa comparado com a população de antes do contato (ARRUDA, 2014). Atualmente a população do povo Rikbaktsa, segundo dados do Sistema de Informação da Atenção à Saúde Indígena (SIASI), é de aproximadamente 1.514 pessoas (ISA, 2016).

Essas pessoas estão distribuídas em mais de trinta aldeias de três Terras Indígenas (TI) demarcadas e homologadas na região noroeste do estado do Mato Grosso (Figura 1), compreendendo os municípios de Brasnorte, Juara e Cotriguaçu (ISA, 2016). 
FIGURA 1 - Terras Indígenas dos Rikbaktsa em Mato Grosso.

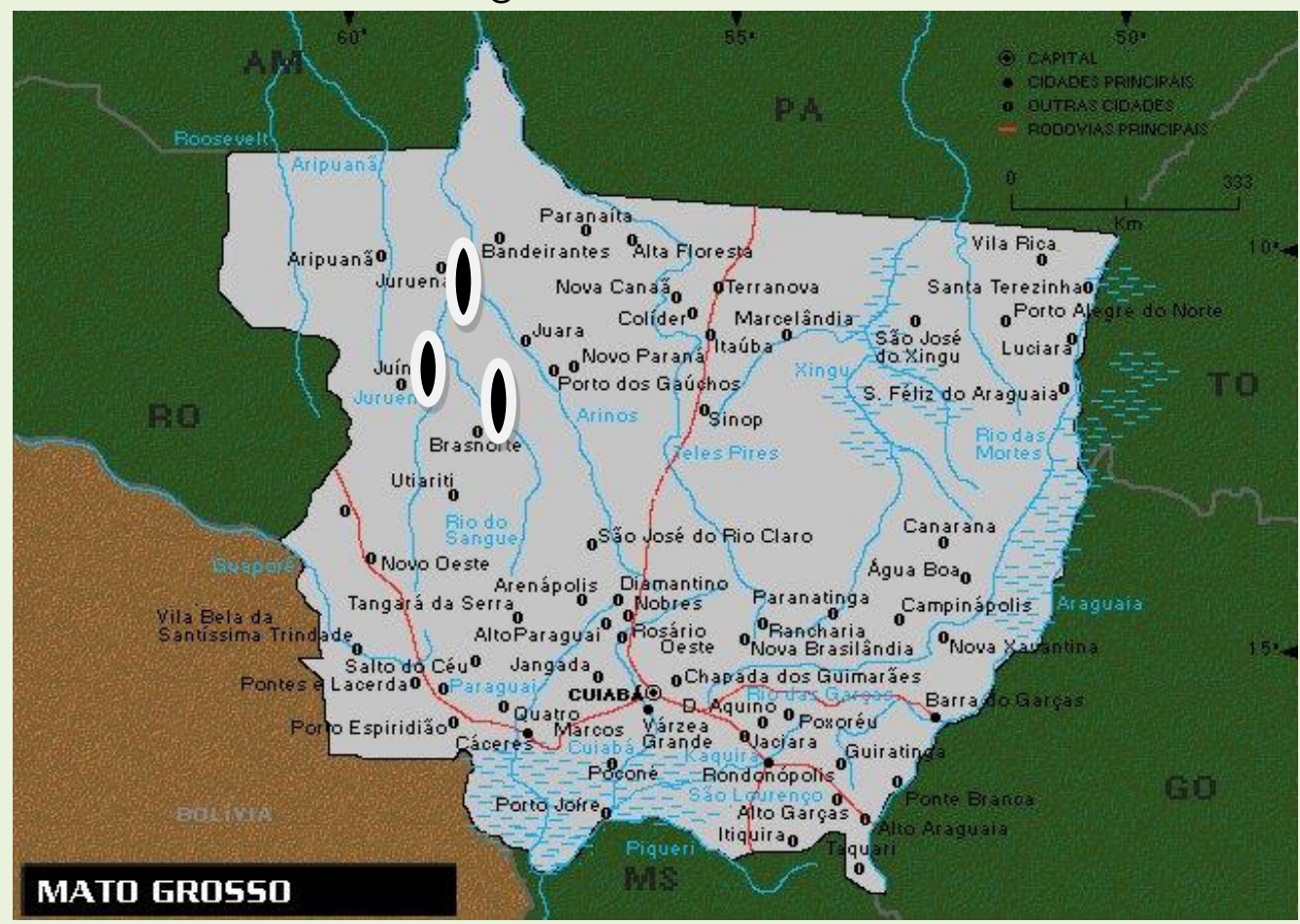

Fonte: Adaptado de http://terranovadonortemt.blogspot.com.br/2008/07/37-mapa-e-hinode-mato-grosso.html

A primeira delas é a TI Erikpatsa, ou Rikbaktsa como foi homologada pelo governo federal em 1969, cuja extensão territorial é de 79.934 hectares aproximadamente, sendo a menor em extensão territorial comparada com as outras TI. Localizada inteiramente no município de Brasnorte - MT, essa área é a que possui o maior número de pessoas e número de aldeias.

Essa $\mathrm{Tl}$ é constituída por vinte e quatro aldeias, que receberam os seguintes nomes: Escolinha; Divisa; Cabecerinha; Boa Esperança; Palmeira do Norte; Barranco Vermelho; Cajueiro; Laranjal; Pedregal; Vale do Sol; União; Primavera; Curva; Curvinha; Segunda; Segurança; Beira Rio; Área Branca; Aldeia Nova; Aldeia Velha; Pedra Bonita; Seringal 01; Seringal 02 e Santa Rita.

A segunda das três terras a ser homologada pelo governo federal, em 1989, é a TI conhecida como Japuíra, na qual esse pesquisador indígena habita. Essa TI fica localizada no município de Juara - MT. Ela também é a segunda em concentração de pessoas e número de aldeias e coincidentemente em extensão territorial. Sua área territorial totaliza 152.509 
hectares aproximadamente e compreende um total de sete aldeias, a saber: Divisa Marcolino; Jatobá; Pé de Mutum; Cerejeira; Japuíra; São Vicente e Castanhal.

A terceira e última TI a ser homologada pelo governo federal, no ano de 1998, foi a TI do Escondido, no município de Cotriguaçu - MT, localizada mais ao norte, na margem esquerda do rio Jurvena. Sua área total mede 168.938 hectares aproximadamente. Essa é a TI que concentra o menor número de habitantes e uma única aldeia, nomeada como Escondido (ISA, 2016).

Cabe aqui registrar que as TI Rikbaktsa, Japuíra e Escondido estão localizadas no entorno da bacia do Jurvena, por isso muitos pesquisadores consideram os Rikbaktsa como sendo os indígenas do Rio Jurvena.

A relação dos Rikbaktsa com a natureza é muito intensa, prova disso é que a forma de organização social adotada por esse povo tradicional envolvem os seres vivos da fauna e flora local, os quais são divididos em dois grandes grupos opostos, mas ao mesmo tempo complementares (ARRUDA, 2014).

Essa divisão social em metades serve para configurar o grau de parentesco e a forma com que organizam a convivência social. Assim, metade da sociedade é associada ao clã da arara amarela, conhecido como Makwaratsa, e outra metade ao clã da arara cabeçuda (arara vermelha), conhecido como Hazobtisa (ARRUDA, 1992).

Ainda segundo a mesma fonte supracitada, as subdivisões do clã da arara amarela (Makwaraktsa) compreendem os seguintes subgrupos: Tsikbaktsa (uma espécie de arara vermelha); Bitsitsiyktsa (um tipo de fruta silvestre); Mubaiknytsitsa (macaco aranha ou quati); Zoktsa (vegetal conhecido como pau torcido, que é um tipo de arbusto); Zuruktsa (animal feroz parecido com a onça, porém já extinto); e Wohorektsa (certo tipo de árvore). Já as subdivisões do clã da arara cabeçuda (Hazobtisa) compreendem: Umahatsaktsa (figueira); Tsuãratsa (macuquinho); Tsawaratsa (árvore do inajá); Bitsiktsa (tucano); Buroktsa (árvore conhecida como pau leiteiro); e Zerohopyryłsa (jenipapo). 
Segundo estudos de Januário et al (2009), o povo Rikbaktsa é rico em crenças e costumes quanto à alimentação. Os autores afirmam que antigamente todos os alimentos produzidos nas roças ou coletados comunitariamente eram conservados em jirau, uma espécie de grade suspensa feita de forquilha e galhos. Já se sabe que houve significativas mudanças nos costumes e nos hábitos alimentares desse povo tradicional, especialmente depois de manterem contato com os não indígenas. Contudo, ainda hoje alguns alimentos tradicionais são cultivados pelos Rikbaktsa e os mais velhos quase sempre consomem somente desses alimentos.

Outro aspecto interessante, apontado pelo autor supracitado, é que na época de plantação de milho e outras culturas, os Rikbaktsa não podem coletar mel de qualquer abelha para não comprometer a plantação. Segundo a tradição desse povo, acaso for desrespeitado esse costume acredita-se que a plantação apodrecerá (JANUÁRIO et al., 2009). Dessa maneira, no período posterior ao plantio é quando os Rikbaktsa mais recorrem aos frutos nativos.

\section{PROCEDIMENTOS METODOLÓGICOS}

Este estudo etnográfico foi realizado nas aldeias do povo Rikbaktsa, das três terras indígenas, a saber: TI Japuíra, município de Juara - MT, TI Erikpatsa, município de Brasnorte - MT, e TI Escondido, município de Cotriguaçu - MT. A pesquisa etnográfica, segundo Beaud e Weber (2007), pode ser compreendida como uma pesquisa social que investiga determinada cultura pela observação direta e por um período considerável de tempo, o que permite compreender as formas costumeiras de viver desse determinado grupo de pessoas.

O estudo foi realizado em várias etapas, nas aldeias onde moram os anciões. Seu desenvolvimento ocorreu nos anos de 2014 e de 2016. Inicialmente foi solicitada a autorização para a realização da pesquisa, depois foram observados quais são os frutos nativos disponíveis nessa região, que abrange cerrado e floresta amazônica. 
Como instrumentos utilizados para coletar dados, recorreu-se à realização de entrevistas não estruturadas, à observação participante e à produção de ilustrações no formato de desenhos. Esses instrumentos são indicados por Angrosino (2009) para a realização de pesquisas etnográficas e observacionais.

As observações participantes ocorreram nas três áreas do povo Rikbaktsa: terra indígena Japuíra, município de Juara - MT, terra indígena Erikpatsa, município de Brasnorte - MT e terra indígena Escondido, que fica no município de Cotriguaçu - MT. Cabe aqui ressaltar que o pesquisador é indígena e integrante desse povo tradicional, o que viabilizou a realização do estudo.

Antes de iniciar a realização das entrevistas, foi realizada reunião informativa, que contou com a presença de algumas lideranças da comunidade, ocasião em que foi explicado o motivo e os objetivos da pesquisa. Teve também a presença do cacique da aldeia local onde eram feitas as pesquisas. Na ocasião foi informado aos entrevistados que essa pesquisa é um requisito para a produção do Trabalho de Conclusão de Curso (TCC), que ficará disponivel por meio de publicação na universidade e poderá vir a ser divulgada por meio de outros veículos.

Todos os participantes do estudo aceitaram participar voluntariamente da pesquisa, sendo que os mesmos assinaram os Termos de Consentimento Livre e Esclarecido (TCLE) após estarem cientes das finalidades e objetivos. Cabe aqui registrar que, antes mesmo de iniciar a coleta de dados, as lideranças da comunidade já haviam assinado a Carta de Anvência autorizando a realização do estudo.

Foram realizadas entrevistas com consultores nativos, ou seja, com os anciões das aldeias do povo Rikbaktsa, das terras indígenas Japuíra: Aldeia Pé de Mutum, senhores Oseías, Paulo Tsikdi, Marinho e da aldeia Jatobá, senhores Ivan e Salvador. Os encontros com os consultores nativos de outras aldeias foram previamente agendados e realizados na própria localidade onde residem, ou seja, para facilitar o processo, ocorreu o deslocamento do pesquisador até onde moram. 
Cada ancião foi entrevistado de maneira individual, não sendo realizada mais de uma entrevista na mesma semana. Os dados coletados foram registrados em forma escrita, sendo que os consultores nativos forneciam as respostas na língua materna. Por isso, o estudo precisou contar com a ajuda de professores bilíngues da comunidade, na tradução da língua Rikbaktsa para a língua portuguesa ou vice-versa.

Os frutos foram desenhados e, posteriormente, foi descrita a maneira como são utilizados e o período que estão disponíveis para o consumo, a fim de serem catalogados. Os nomes científicos das espécies vegetais catalogadas foram identificados ao comparar com as 500 espécies apresentadas no guia de campo sobre a vegetação do cerrado, publicado pelo Ministério do Meio Ambiente (MEDEIROS, 2011) e com o livro sobre as frutas nativas amazônicas, publicado pela Embrapa (SHANLEY; SERRA; MEDINA, 2010).

\section{RESULTADOS E DISCUSSÃO}

A descrição do nome na língua materna, nome popular em língua portuguesa, nome científico e modo de consumo dos 32 frutos nativos catalogados está contida no Quadro 1.

QUADRO 1 - Características gerais das frutas e seus modos de consumo

\begin{tabular}{|c|c|c|c|}
\hline $\begin{array}{l}\text { Nome na língua } \\
\text { materna }\end{array}$ & $\begin{array}{l}\text { Nome popular em } \\
\text { língua portuguesa }\end{array}$ & $\begin{array}{l}\text { Nome } \\
\text { científico }\end{array}$ & Como é consumido \\
\hline Aboho & $\begin{array}{l}\text { Pimenta do mato } \\
\text { grande }\end{array}$ & $\begin{array}{l}\text { Erythroxylum } \\
\text { sp }\end{array}$ & $\begin{array}{l}\text { Pode ser comido e fazer chicha } \\
\text { (precisa ser fervida). }\end{array}$ \\
\hline Abinõk & $\begin{array}{l}\text { Acerola do mato } \\
\text { ou cerejeira-do- } \\
\text { Pará }\end{array}$ & $\begin{array}{l}\text { Malpighia } \\
\text { emarginata }\end{array}$ & $\begin{array}{l}\text { Serve para comer, só tem um } \\
\text { caroço e libera muito líquido } \\
\text { quando tirado do pé. }\end{array}$ \\
\hline Abinõkza & Pitanga do mato & $\begin{array}{l}\text { Myrcia } \\
\text { pseudosplen } \\
\text { dens }\end{array}$ & $\begin{array}{l}\text { Este fruto não libera líquido } \\
\text { quando colhido, está pronto } \\
\text { quando apresenta a cor } \\
\text { amarelada. }\end{array}$ \\
\hline Atsik & $\begin{array}{l}\text { Mão de jabuti ou } \\
\text { marolo }\end{array}$ & $\begin{array}{l}\text { Annona } \\
\text { crassiflora }\end{array}$ & $\begin{array}{l}\text { Serve somente para comer, não } \\
\text { é possível fazer suco e nem } \\
\text { chicha. }\end{array}$ \\
\hline Awitsunu & $\begin{array}{l}\text { Cacau nariz de } \\
\text { quati }\end{array}$ & $\begin{array}{l}\text { Pachira } \\
\text { aquática }\end{array}$ & Serve somente para comer. \\
\hline Bamy & $\begin{array}{l}\text { Pimentinha do } \\
\text { mato pequena }\end{array}$ & $\begin{array}{l}\text { Erythroxylum } \\
\text { sp }\end{array}$ & $\begin{array}{l}\text { Serve para comer e também } \\
\text { para fazer chicha (fervida). }\end{array}$ \\
\hline
\end{tabular}




\begin{tabular}{|c|c|c|c|}
\hline Hokto & $\begin{array}{lr}\text { Não } & \text { conhecida } \\
\text { em } & \text { língua } \\
\text { portuguesa } & \end{array}$ & $\begin{array}{l}\text { Não } \\
\text { identificada }\end{array}$ & $\begin{array}{l}\text { É colhido quando está verde e } \\
\text { serve somente para comer. }\end{array}$ \\
\hline Hoktorire & $\begin{array}{lr}\text { Não } & \text { conhecida } \\
\text { em } & \text { língua } \\
\text { portuguesa } & \end{array}$ & $\begin{array}{l}\text { Não } \\
\text { identificada }\end{array}$ & $\begin{array}{l}\text { Assim como o fruto anterior, } \\
\text { serve somente para comer. }\end{array}$ \\
\hline Bamyhiri & $\begin{array}{l}\text { Pimenta amarela } \\
\text { do mato ou } \\
\text { cumari-do-pará }\end{array}$ & $\begin{array}{l}\text { Capsicum } \\
\text { chinense }\end{array}$ & Serve somente para comer. \\
\hline Bamyekpe & $\begin{array}{l}\text { Pimentinha do } \\
\text { mato maior }\end{array}$ & $\begin{array}{l}\text { Erythroxylum } \\
\text { sp }\end{array}$ & $\begin{array}{l}\text { Serve somente para comer e só } \\
\text { tem um caroço. }\end{array}$ \\
\hline Tomaze & $\begin{array}{l}\text { Goiaba-do-mato } \\
\text { ou feijoa }\end{array}$ & $\begin{array}{l}\text { Acca } \\
\text { sellowiana }\end{array}$ & $\begin{array}{l}\text { Serve somente para comer, tem } \\
\text { vários caroços. Aparência } \\
\text { similar à gabiroba. }\end{array}$ \\
\hline Maze & Jatobá grande & $\begin{array}{l}\text { Hymenaea } \\
\text { courbaril }\end{array}$ & $\begin{array}{l}\text { Serve tanto para comer quanto } \\
\text { fazer suco. }\end{array}$ \\
\hline Matsaek & Jatobazinho & $\begin{array}{l}\text { Hymenaea } \\
\text { stilbocarpa }\end{array}$ & $\begin{array}{l}\text { Pode ser consumido do mesmo } \\
\text { modo que o fruto anterior. }\end{array}$ \\
\hline Waijak & Cacau & $\begin{array}{l}\text { Theobroma } \\
\text { cacao }\end{array}$ & Serve para comer e fazer suco. \\
\hline Pozokyry & Bacuri & $\begin{array}{l}\text { Platonia } \\
\text { insignis }\end{array}$ & $\begin{array}{l}\text { Tem até } 4 \text { caroços. Serve para } \\
\text { comer e fazer suco. }\end{array}$ \\
\hline Pozokyryza & $\begin{array}{l}\text { Bacurizinho do } \\
\text { brejo }\end{array}$ & $\begin{array}{l}\text { Rheedia } \\
\text { gardneriana }\end{array}$ & $\begin{array}{l}\text { Tem a mesma utilidade do fruto } \\
\text { anterior, porém é um pouco } \\
\text { menor no tamanho. }\end{array}$ \\
\hline Sokorohaek & $\begin{array}{l}\text { Cacau cabeça de } \\
\text { cutia }\end{array}$ & $\begin{array}{l}\text { Theobroma } \\
\text { mariae }\end{array}$ & Serve somente para comer. \\
\hline Iharahokota & Mamão do mato & $\begin{array}{l}\text { Jaracatiá } \\
\text { spinosa }\end{array}$ & $\begin{array}{l}\text { Serve somente para comer, } \\
\text { tanto verde quanto maduro. }\end{array}$ \\
\hline Tsamyekawy & Pitomba do mato & $\begin{array}{l}\text { Talisia } \\
\text { esculenta }\end{array}$ & $\begin{array}{l}\text { Serve somente para comer, } \\
\text { assim que retirado do pé. }\end{array}$ \\
\hline Tometsa & $\begin{array}{lr}\text { Não } & \text { conhecida } \\
\text { em } & \text { língua } \\
\text { portuguesa } & \\
\end{array}$ & $\begin{array}{l}\text { Não } \\
\text { identificada }\end{array}$ & $\begin{array}{l}\text { Serve somente para comer } \\
\text { assim que retirado do pé. }\end{array}$ \\
\hline Hahazikhara & $\begin{array}{l}\text { Fruto do roncador } \\
\text { ou croada }\end{array}$ & $\begin{array}{l}\text { Mouriri } \\
\text { elliptica }\end{array}$ & $\begin{array}{l}\text { Serve somente para comer, } \\
\text { assim que retirado do pé. }\end{array}$ \\
\hline Mazikpinuhã & Mão de gato & $\begin{array}{l}\text { Zanthoxylum } \\
\text { pohlianum }\end{array}$ & Serve somente para comer. \\
\hline Zuru & Buriti ou miriti & $\begin{array}{l}\text { Mauritia } \\
\text { flexuosa }\end{array}$ & $\begin{array}{l}\text { Serve para comer e fazer suco } \\
\text { com mel de abelha. }\end{array}$ \\
\hline Watsõetsa & Bacaba & $\begin{array}{l}\text { Oenocarpus } \\
\text { bacaba }\end{array}$ & Serve para comer e fazer suco. \\
\hline Oktsatatsa & Patauá & $\begin{array}{l}\text { Oenocarpus } \\
\text { bataua }\end{array}$ & Serve para comer e fazer suco. \\
\hline Tsawaraktsa & Inajá & $\begin{array}{l}\text { Attalea } \\
\text { maripa }\end{array}$ & Serve para comer e fazer suco. \\
\hline Tsaziukzatsa & $\begin{array}{lr}\text { Não } & \text { conhecida } \\
\text { em } & \text { língua } \\
\text { Portuguesa } & \\
\end{array}$ & $\begin{array}{l}\text { Não } \\
\text { identificada }\end{array}$ & Serve somente para comer. \\
\hline Oktsoto & Cajazinho & $\begin{array}{l}\text { Spondias } \\
\text { mombin L. }\end{array}$ & Serve somente para comer. \\
\hline Peky & Limão-do-mato & Randia ferox & $\begin{array}{l}\text { Serve somente para comer } \\
\text { quando está madura. }\end{array}$ \\
\hline Zuruza & Buritirana & $\begin{array}{l}\text { Mauritiella } \\
\text { armata }\end{array}$ & Serve para comer e fazer suco. \\
\hline Pitsi & Castanha-do-Brasil & Bertholletia & Serve para comer, tirar óleo \\
\hline
\end{tabular}




\begin{tabular}{|l|l|l|l|}
\hline & $\begin{array}{l}\text { ou castanha-do- } \\
\text { pará }\end{array}$ & $\begin{array}{l}\text { para cozinhar, fazer mingau de } \\
\text { peixe e animais. Utilizado } \\
\text { principalmente nas festas } \\
\text { tradicionais. }\end{array}$ \\
\hline Arabata & $\begin{array}{l}\text { Cajuzinho do do } \\
\text { cerrado ou cajuí }\end{array}$ & $\begin{array}{l}\text { Anacardium } \\
\text { humile }\end{array}$ & $\begin{array}{l}\text { Serve para comer, fazer suco e } \\
\text { para fazer isca para pescar. }\end{array}$ \\
\hline
\end{tabular}

Fonte: Dados coletados e consultados em Medeiros (2011) e em Shanley, Serra e Medina (2010).

Observa-se que não foi possível identificar de apenas quatro desses frutos nativos o nome popular em língua portuguesa e consequentemente também não se obteve o nome científico da espécie vegetal. Quanto à forma que são consumidos, segue uma descrição mais detalhada de cada um desses frutos nativos.

A aboho, conhecida popularmente pelo nome não indígena como pimenta grande do mato (Figura 2A), é uma fruta de cor avermelhada. A época de colheita deste fruto corresponde aos meses de setembro e outubro, e pode ser comido na hora que foi retirado do pé. Também serve para fazer chicha, um tipo de bebida muito apreciada entre os indígenas. Nesse processo, o fruto é colocado em um pilão e socado com caroço. Logo em seguida, é colocado em uma panela e levado ao fogo para ser fervido. Depois de cozido, é retirado do fogo para esfriar e é servido, podendo ser adoçado com mel de abelha. Esse fruto, por ser muito gostoso, também é preferido pelos animais e pássaros como: macaco, arara, macuco, jacu e juriti.

Sobre a abinõk, ou acerola do mato (Figura 2B), pode-se dizer que é uma fruta bastante comum na região do povo Rikbaktsa, sendo de cor avermelhada quando madura. A época de frutificação do abinõk é no mês de dezembro. Uma das características dessa fruta é possuir muito leite (líquido da fruta não totalmente madura) que pode cortar ou arranhar boca e língua de quem a come. Por isso, deve ser consumida quando estiver bem madura.

Essa fruta pode ser colhida ainda verde, no entanto, é necessário deixá-la em local fresco para amadurecer completamente. O povo 
Rikbaktsa, quando colhe frutos da mata, não pode derrubar o pé, tem que subir e cortar os galhos que têm frutos para que, assim, sempre no ano seguinte, possa colher outras vezes.

Quanto à abinõkza, ou pitanga do mato, como é conhecida pelo nome não indígena (Figura $2 \mathrm{C}$ ), esta é uma fruta da cor amarela que é produzida na época da seca, geralmente só se produz na margem do rio e córregos. Esta fruta pode ser consumida quando retirada do pé ou pode ainda ser guardada em casa por no máximo quatro dias dentro do cesto.

Já a atsik, (Figura 2D), é uma fruta conhecida por mão de jabuti pelo o povo Rikbaktsa. Na região onde esse povo habita, a atsik é encontrada facilmente pela grande quantidade de árvores existentes nas florestas. Esta fruta é colhida da árvore quando está madura e deve ser comida na mesma hora. Ela tem gosto doce e azedo ao mesmo tempo e, por isso, é uma fruta muito gostosa. Na sua época, os jabutis ficam gordos e os Rikbaktsa matam e comem, assim como outros animais da mata quando estão gordos. Então nessa época procuram jabutis, principalmente, embaixo dessas fruteiras.

A fruta awitsunu, conhecida como cacau nariz de quati (Figura 2E), é uma qualidade de cacau nativo que existe em nossa região, é quase igual o cacau da Bahia, mas é um pouco menor. A época de coletar esse fruto compreende o final de novembro, todo o mês de dezembro e início de janeiro, quando amadurece e fica da cor amarelada, o gosto é o mesmo do cacau da Bahia. É muito difícil encontrar esse fruto maduro, porque os animais o apreciam demais. A árvore é bem pequena, ou seja, é facilmenter alcançado com as mãos, sem ter o trabalho de subir na árvore para colher. Seu tronco não possui galhos e assim frutos nascem grudados ao tronco com um palmo de altura do chão ou pouco mais.

Por sua vez, a bamy, ou pimentinha pequena do mato (Figura 2F), é uma fruta da cor vermelha e a época da colheita é o mês de outubro. A árvore chega medir aproximadamente 20 metros de altura e seu tronco chega até $50 \mathrm{~cm}$ de diâmetro. Se parece com a pimenta devido a sua coloração avermelhada, por isso é conhecida também pelo nome de 
pimenta do mato. O fruto serve para comer no momento que é retirado do pé, tem gosto azedo e doce, servindo para comer e fazer chicha. O fruto é socado no pilão e cozido aproximadamente uma hora no fogo, depois de pronta, a chicha é servida e adoçada com mel de abelha.

FIGURA 2 - llustrações de algumas frutas catalogadas

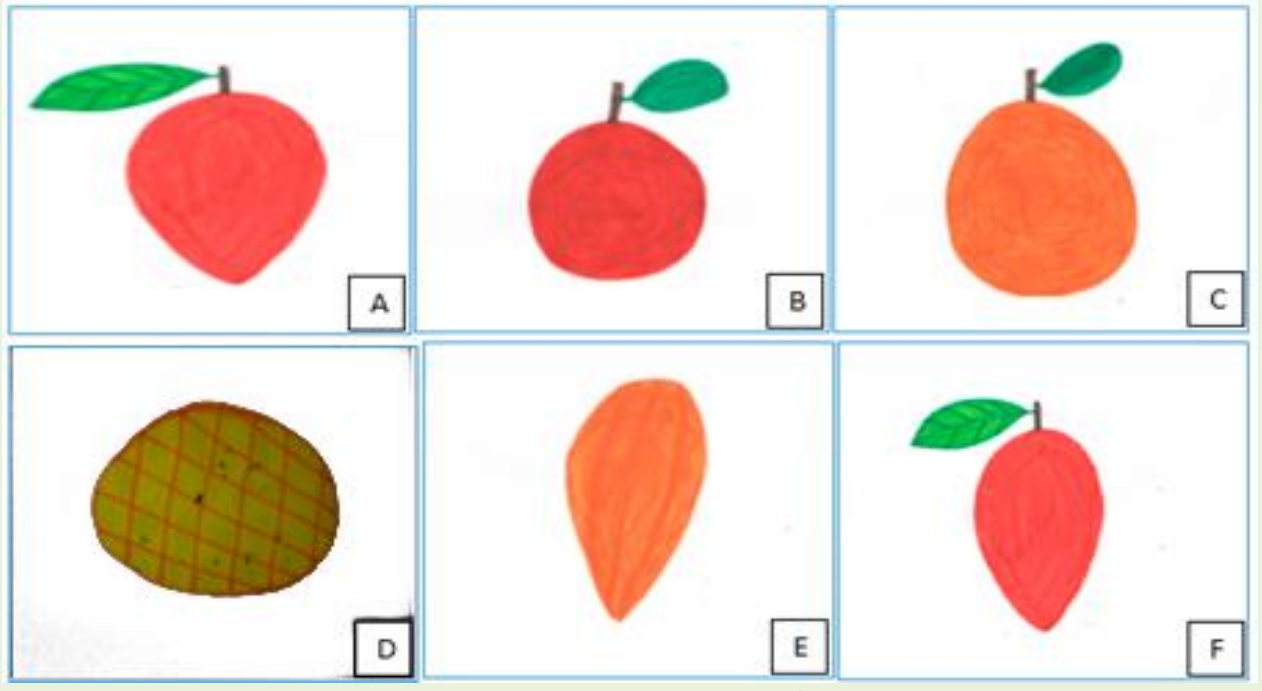

Fonte: Elaboradas pelo autor indígena (2016).

A hoktorire ou algodoeira amarela (Figura 3B), também é um fruto nativo que serve de alimento para o povo Rikbaktsa na região da TI Japuíra. É muito raro encontrar essa espécie na mata. Geralmente, essa fruta se encontra no local distante da margem do rio. Ela também é coletada quando ainda verde. É colocado no xiri, que é um tipo de balaio feito de palha de açaí ou de patuá, uma espécie de palmeira. Só é consumido quando está completamente maduro.

Outro fruto catalogado é o conhecido como bamyhiri, ou pelo nome não indígena, pimenta amarela do mato (Figura $3 \mathrm{C}$ ). Este é outro tipo de fruto que o povo Rikbaktsa utiliza em sua alimentação, tem a cor amarelada quando madura e seu gosto é bem doce, só serve para ser comido logo que é retirado do pé, pois se for guardado em casa, pode durar no máximo de um a dois dias, depois estraga.

A bamyekpe (Figura 3D) é uma fruta conhecida também como uma espécie de pimentinha do mato, a época dela é no inverno, lá pelo mês de maio. É uma fruta de cor avermelhada. O povo Rikbaktsa come esta fruta no 
mesmo momento que ela é retirada do pé. Também pode ser feita a chicha do bamyekpe, se socada no pilão com o caroço, depois de socada, é colocada em uma panela para ser fervida, até ficar no ponto para ser servida, pode ser adoçada com mel de abelha ou com açúcar dos não indígenas.

A tomaze, ou goiaba do mato (Figura 3E), tem sua época de frutificação entre os meses de fevereiro e março. O lugar apropriado para encontrá-la é em lugares de brejo. Quando está madura ela racha toda por fora e cai do pé por si mesma, tem um cheiro muito agradável e o caroço é igual ao da ata, ou da graviola. Por dentro esta fruta é bem vermelha, também é colhida quando se percebe que está quase no ponto de amadurecer. Na mata, ao passar por perto de frutos maduros, percebe se essa fruta pelo cheiro característico, situação em que tem muitas delas já caídas no chão.

A fruta conhecida como maze pelos indígenas, ou jatobá grande pelos não indígenas (Figura 3F), tem a cor marrom escuro, quase preta. Sua época de colheita é o período de maio a setembro, quando está madura, ela cai do pé por conta própria. Por dentro tem alguns caroços grandes e pode ser consumida de forma natural ou em forma de suco. Da semente fazemos também colares que usamos ou comercializamos, por isso é de grande importância para nós, pois é uma fonte de renda para o povo Rikbaktsa. A casca do tronco é utilizada para fazer remédio natural para tosse, evita a bronquite e doenças respiratórias. A casca é retirada do tronco e fervida em uma vasilha até sair o licor da cor do vinho, é colocado o açúcar, o remédio fica igual ao xarope comprado na farmácia. Quanto à dosagem, o xarope é dado em doses correspondentes a uma colher de sopa, principalmente, para crianças.

O povo Rikbaktsa usa a resina desta árvore para fazer fogo, flechas de ponta imprensada e colocar nos colares, dentes dos animais como: porco, queixada, cateto, capivara, macaco quati, veado e irara. Esse fruto tem poupa sequinha igual à farinha de trigo, a cor marrom e o cheiro são bem fortes. Por isso, as crianças pequenas não podem comer. Se colocada em 
muita quantidade na boca pode até entalar de tão seca que é. Os animais, quando descobrem a disponibilidade desses frutos, não deixam nada no chão, ou seja, comem tudo, principalmente a paca e o veado (mateiro). Segundo a história da mitologia Rikbaktsa, a onça tem olhos claros, porque foiram feitos com resina do jatobá.

FIGURA 3 - Ilustrações de outras frutas catalogadas

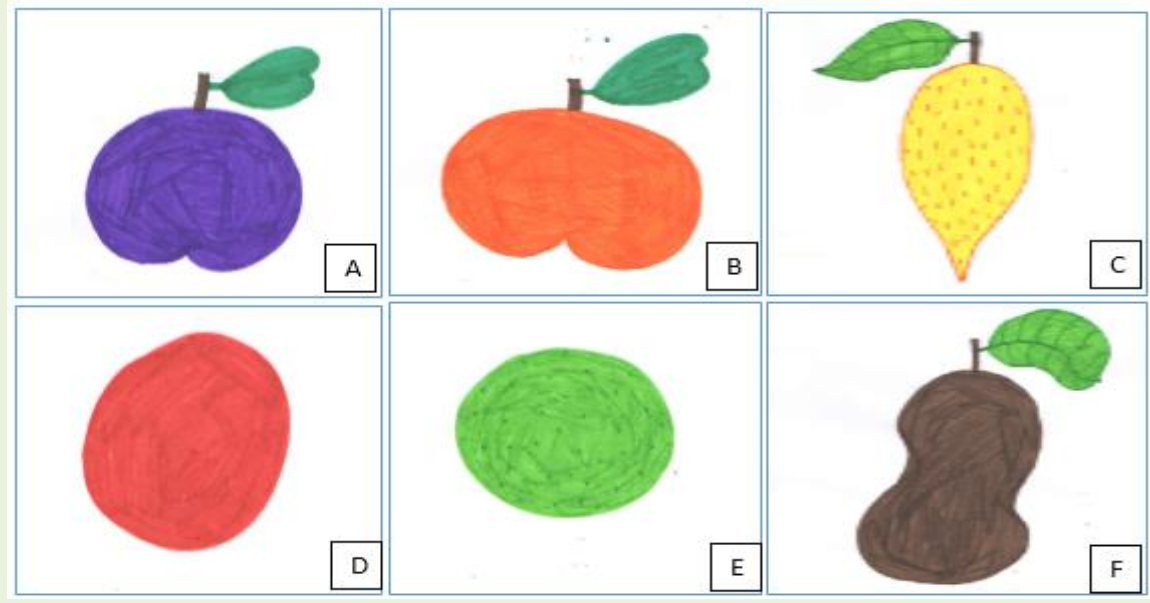

Fonte: Elaboradas pelo autor indígena (2016).

O matsaek, ou jatobazinho como é conhecido pelo não indígena (Figura 4A), é uma espécie de jatobazinho do mato, também conhecido como jatubinha, ele também é consumido do mesmo jeito do jatobá grande, fazemos suco também. Sua colheita é na mesma época do maze.

O Waijak, ou cacau (Figura 4B), é um tipo de cacau nativo do mato da região e pode ser encontrado com facilidade. A época de colher $O$ cacau é no final do período de seca, entre os meses de agosto e setembro. O consumo desse fruto é bastante intenso, principalmente, pelas mulheres e crianças dessa etnia. Os Rikbaktsa consomem desde o momento em que os frutos são retirados do pé. Também é feito suco da polpa do cacau, do tronco é muito utilizado como lenha para cozinhar os alimentos. O sabor dessa fruta é o mesmo de um pé para o outro, o que varia é que algumas árvores produzem frutos mais doces, enquanto outras produzem frutos muito azedos, estes, ninguém apanha para comer. As mulheres Rikbaktsa com idade um pouco mais avançada geralmente furam o cacau com graveto 
de pau verde para revirar os caroços e poupa. Dessa forma conseguem extrair mais suco da fruta.

O Pozokyry, também conhecido como bacuri (Figura 4C), é uma espécie de fruto nativo comumente encontrado na região. Sua época de colheita também compreende o período da seca, que se estende de maio a setembro na região Centro-oeste, porém somente é colhido nos meses de julho e agosto. Quando está madura, essa fruta apresenta cor amarelada e também tem bastante polpa na casca, por isso o povo Rikbaktsa tem o costume de deixar pelo menos dois dias, a partir do dia que o fruto foi coletado do pé, para serem consumidos. O tronco, as folhas e as raízes não têm utilidade, pois somente o fruto serve de alimento para os Rikbaktsa.

O pozokyryza, ou bacurizinho do brejo (Figura 4D) é outra espécie de fruto de qualidade parecida à anterior, de grande sabor e aroma agradável. Porém, essa fruta é encontrada no brejo, ou seja, onde há muita água. Sua época de frutificação vai de outubro a abril, que é a época de chuvas no Mato Grosso. Raízes e folhas não servem como erva medicinal, somente o fruto é utilizado na alimentação. Também pode ser feito suco da polpa do bacurizinho do brejo.

Outra fruta catalogada foi a sokorohaek, ou cacau cabeça de cutia (Figura 4E). Essa é mais uma espécie de cacau da região. Porém é muito diferente do waijak descrito anteriormente nesta pesquisa. Sua casca é lisa, quando maduro é amarelado igual as outras qualidades de cacau, no entanto é bem mais doce. Dele não se costuma fazer suco, apesar de ter mais polpa que as outras espécies. A sua casca é bem mais frágil e se quebra com maior facilidade. Seu tronco é bem mais baixo, raízes e folhas não servem como erva medicinal. Essa é uma árvore da espécie de cupuaçu nativa da região e abundante na TI Escondido.

A iharahokota, também conhecido na língua portuguesa como mão do mato ou pariri (Figura 4F), é uma árvore cujo tronco mede no máximo 60 metros de altitude. Seu fruto é similar ao mamão comum. Também não muda a coloração depois que está madura, ou seja, continua com a casca na cor verde. Seu tronco serve para fazer a cobertura da casa ou também 
para fazer parede. O fruto tem gosto muito azedo, e tem caroço do tamanho do caroço do jatobá. Quando é a época de amadurecer, os Rikbaktsa têm costume de esperar debaixo da árvore para sondar animais que se alimentam por lá, como exemplo, anta, cateto, veado e porcão. A época que amadurece é no período da seca.

FIGURA 4 - llustrações de mais frutas catalogadas

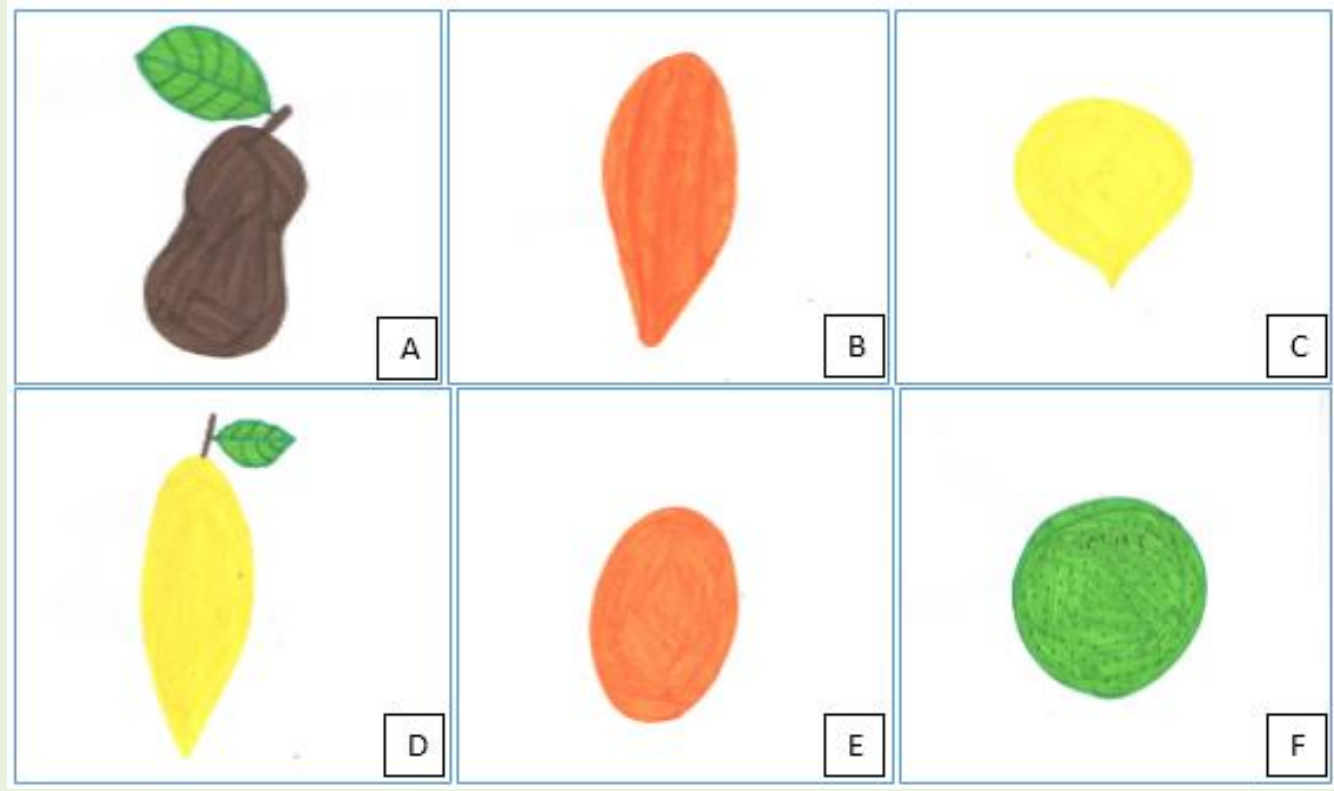

Fonte: Elaboradas pelo autor indígena (2016).

A tsamyekawy, ou pitomba do mato (Figura 5A), é um fruto nativo que existe na região em bastante quantidade. É um fruto muito consumido nos meses de fevereiro e março. Quando está maduro é de cor amarelada, seu tronco é bem baixo, raízes e folhas não servem como erva medicinal.

A fruta conhecida como tometsa, ou cabriteira pelos indígenas, pois não se conhece o nome desta fruta em língua portuguesa (Figura 5B), é uma espécie de fruto nativo que costuma ser encontrado no cerrado, principalmente em lugares arenosos, mas também pode ser encontrado nas florestas nativas do povo Rikbaktsa. Sua época de colheita é durante o período de seca, quando madura sua cor é preta bem escura e tem um cheiro muito agradável. A cabriteira é parecida com os testículos de cabrito, por isso, esta fruta é assim conhecida. Na época quando estão maduros, os Rikbaktsa gostam de pescar debaixo de sua sombra quando as árvores 
estão próximas ao rio ou utilizando-os como isca, pois seus frutos atraem muitos peixes, tais como, matrinxã, piau, pacu, entre outros.

A hahazikhara, também chamada de fruta do roncador (Figura 5C), é uma fruta que pode ser encontrada no mato $e$ às margens do rio e duas qualidades podem ser encontradas na região: casca dura e casca mole e amadurecem na época da seca. É um fruto que é muito bom para utilizar como isca na pesca, mas também serve como alimento para os Rikbaktsa, principalmente, as crianças que gostam muito de comê-lo quando é a época.

A mazikpinuhã, ou mão de gato (Figura 5D), é uma fruta muito consumida quando é a época (final da chuva). Sua forma se assemelha com a pata de um gato e por isso tem este nome em português. Quando está madura é da cor verde, seu caroço é semelhante ao da pitanga.

O zuru, ou buriti como é conhecida pelo não indígena (Figura 5E), é uma espécie de palmeira encontrada sempre perto da água e na época de amadurecer seus frutos que ficam presos em cachos, isso acontece no verão. Quando estão maduros os Rikbaktsa têm o costume de subir em outra árvore mais próxima para cortar os cachos, evitando assim derrubar o pé. A palha também serve para fazer a cobertura da casa. Quando retirados do pé, os frutos precisam ficar guardados em casa pelo menos por três dias, isso quando retirado na época certo. Depois que estão no ponto, os frutos são colocados pelas mulheres em uma vasilha e levados ao fogo, ou então, são deixados fora da casa para que a água esquente com o calor do sol. Enquanto não tiver com a água bem quente, não se pode ficar mexendo no fruto que está ali para amadurecer. As mulheres dizem que se mexer o fruto antes da hora, ele endurece e não amolece mais. Quando está maduro, as mulheres fazem a chicha, colocam no pilão e socam bem devagarzinho, com bastante cuidado para não quebrar os caroços. A chicha pode ser adoçada com mel de abelha ou com açúcar dos não indígenas. A raiz na cultura Rikbaktsa serve para banhar crianças recém-nascidas para que possam engordar e ficar bem fortes e bonitas. 
Outra fruta catalogada foi a watsõetsa, ou bacaba (Figura 5F), que também é uma espécie de palmeira encontrada nos lugares secos. Essa planta é própria da floresta amazônica e sua época de frutificação é o período da seca, se estendendo de janeiro a maio. Onde os Rikbaktsa habitam há bastante, principalmente nas ilhas. Sua fruta é do tipo da jabuticaba, quando está madura, o povo também tem o costume de subir na árvore para tirar os cachos que estão maduros.

O modo de preparar a watsõetsa é colocando-a em uma vasilha com água para mornar, a água não pode estar muito quente. Quando está no ponto, fica bem mole, depois é colocada no pilão e socada até soltar toda a polpa, logo em seguida é colocada em uma vasilha com água e adoçada para beber.

FIGURA 5 - Ilustrações de outras frutas catalogadas

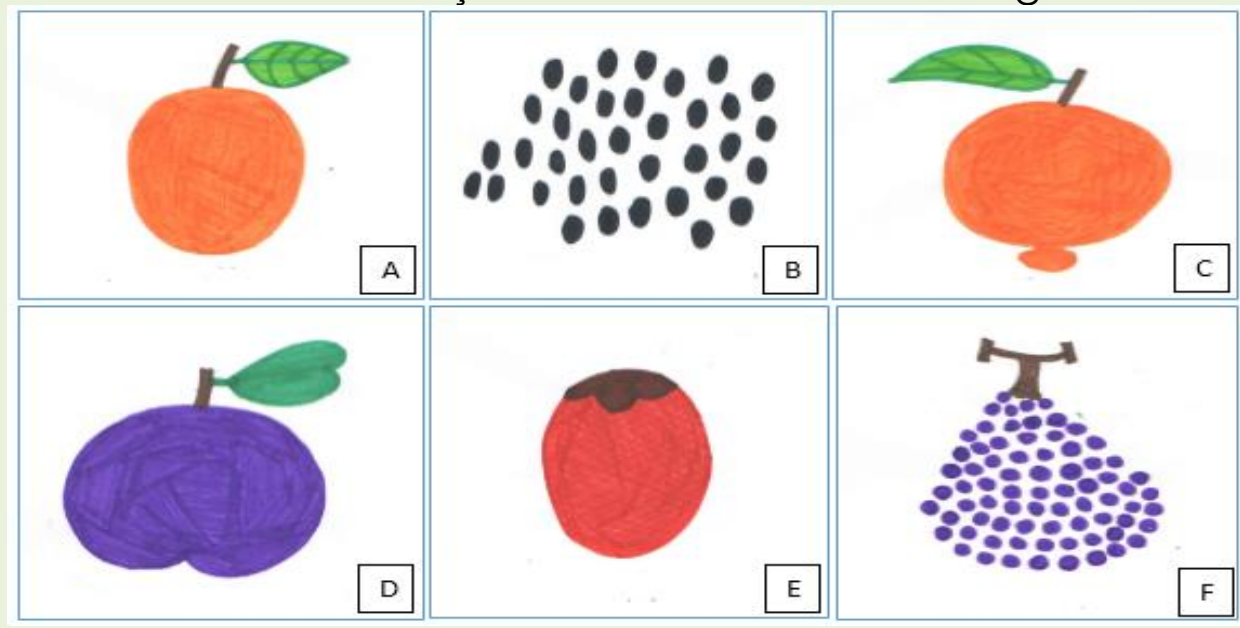

Fonte: Elaboradas pelo autor indígena (2016).

A oktsatatsa, ou patuá (Figura 6A), também é uma espécie de palmeira quase igual à watsõetsa, anteriormente descrito, porém seu tronco e fruto são maiores, também tem o mesmo processo e utilidade do watsõetsa. A palha serve para fazer a cobertura da casa tradicional. Os frutos demoram a amadurecer e sua colheita ocorre entre julho e setembro.

A fruta conhecida por tsawaraktsa, ou inajá (Figura 6B), é uma espécie de palmeira bastante comum em nossa região, a época da colheita e consumo inicia em janeiro e se estende até junho. O fruto é cozido, depois é feito o suco, porém pode ser consumido também em sua forma natural, as 
mulheres utilizam o caroço para fazer colares e brincos para uso próprio ou comercialização, o que serve de uma fonte de renda para as famílias.

O povo Rikbaktsa usa a palha para fazer casa tradicional mykyhy e também para fazer cestos ou xiri, como é chamado pelos Rikbaktsa. Antigamente era produzido sal, utilizando o broto dessa palmeira, mas atualmente não costumamos mais fazê-lo porque é um processo muito difícil, cheio de regras do passado e por ter sido introduzido o consumo do sal dos não índios nas nossas comunidades.

A tsaziukzatsa, ou piuvinha (Figura $6 \mathrm{C}$ ), é um tipo de fruto nativo que tem bastante em nossa região, quando está madura, fica de cor amarelada, tem cheiro muito forte, gosto azedo, sua época é na época da seca. Os Rikbaktsa sobem no pé, cortam os galhos e colhem os frutos quando está maduro.

O oktsoto, popularmente conhecido como cajazinho (Figura 6D), é um tipo de fruto nativo típico do cerrado que é muito consumido de setembro a novembro. Pode ser encontrado tanto nas margens dos rios e córregos, quanto na mata. As raízes e folhas não servem como erva medicinal. Quando a árvore fica na margem de rios e seus frutos maduros caem na água, servem como isca para pescar peixes, principalmente a matrinxã e o pacu.

O peky, também conhecido como limão-do-mato (Figura 6E) é um tipo de fruto que não existe na TI Japuíra, mas tem em outra região onde está localizada outra área do povo Rikbaktsa. O peky frutifica de dezembro a março. Além de ser muito conhecido é bastante consumido na alimentação desse povo tradicional.

A zuruza, ou buritirana (Figura 6F), é um tipo de palmeira que só há na margem do rio. Para comer ou fazer chicha é o mesmo procedimento que é feito com o zuru. A época em que estão maduros é entre os meses de agosto e novembro. Os Rikbaktsa gostam de pescar em lagos rasos, porque pegam muitos peixes debaixo do zuruza. Não dá para subir no seu tronco, pois têm muitos espinhos. 
Outro fruto catalogado é nomeado pitsi pelos indígenas e castanhado-Brasil pelos não indígenas (Figura 6G). Este é um tipo de fruto nativo bastante resistente encontrado nas regiões de floresta amazônica e a época de colheita se estende de outubro a março. O pitsi é um alimento que serve de fonte de renda para toda a comunidade Rikbaktsa e dele ainda se faz mingau misturado com caça do mato, peixe e pássaros. Retiramos o leite e o óleo para cozinhar os alimentos. Quando tem festa tradicional, é preparado o mingau em grande quantidade. Cada clã faz o seu mingau separado, no final é dividido entre os participantes da festa. Da massa também é feito beiju, que se assemelha à tapioca do não indígena, misturado com banana ou massa de milho socado.

O arabata, ou caju nativo (Figura $6 \mathrm{H}$ ), é também um fruto muito consumido na alimentação do povo Rikbaktsa. A época da colheita se estende de setembro a dezembro e pode ser consumido de várias maneiras, os mais jovens fazem suco e os de mais idade (quando o caju é doce) costumam ralar a castanha do Brasil e misturar com caju ralado. Quando está na época do caju amadurecer, os Rikbaktsa têm costume de pescar porque é o mesmo período em que há muita matrinxã, uma espécie de peixe.

Os de mais idade falam para os mais novos que eles não podem comer caju com castanha ralado em ralador de alumínio por que dizem que os dentes caem. Tem época do ano que cajueiros ficam com muitas larvas (coró). O povo Rikbaktsa costuma consumir essas larvas torradas ou põem no mingau de castanha-do-Brasil. As larvas do cajueiro fazem das folhas embrulhos e se escondem para os pássaros não as comerem. As larvas geralmente ficam todas debaixo do cajueiro ou em seu tronco. 
FIGURA 6 - llustrações das últimas frutas catalogadas

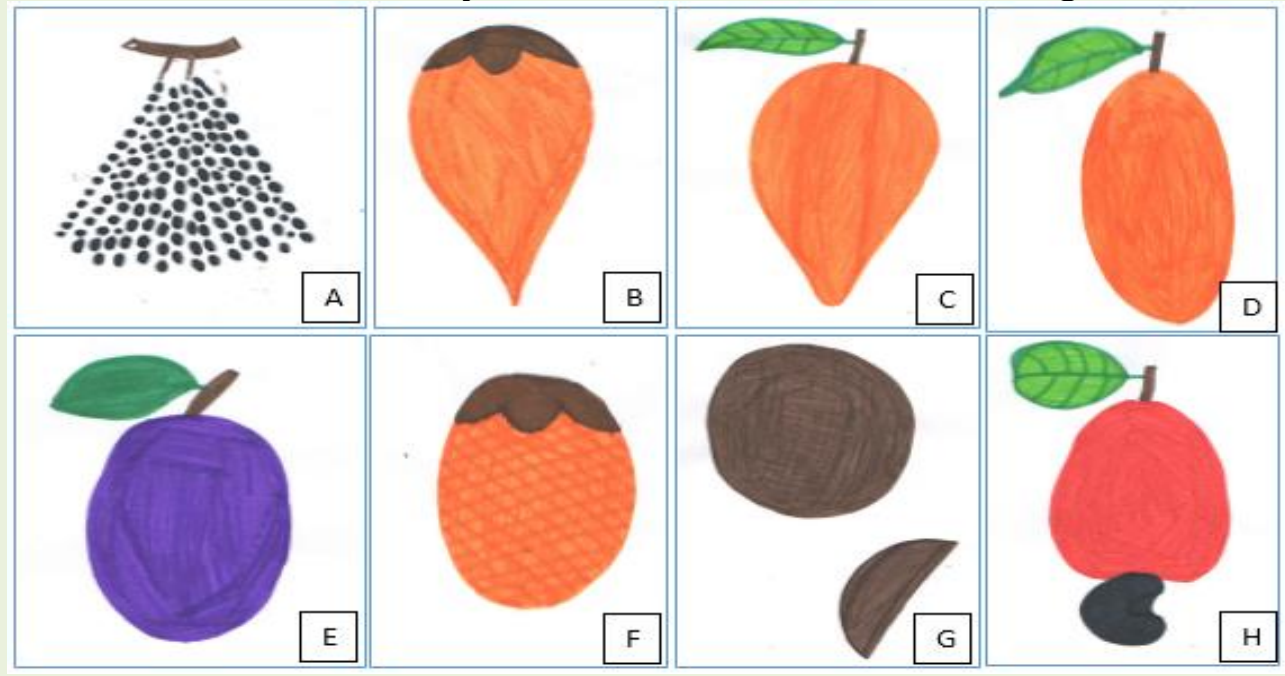

Fonte: Elaboradas pelo autor indígena (2016).

Para levantar o ciclo sazonal dos frutos, foi preciso realizar observações sistemáticas por um período de observação superior a dois anos, o que permitiu confirmar o período de frutificação das espécies investigadas. Essa etapa da pesquisa permitiu que fosse sistematizado o período em que se dispõe dessas espécies frutíferas nativas que o povo consome. No Quadro 2 consta o período sazonal de colheita dessas frutas catalogadas para consumir na alimentação do povo Rikbaktsa.

QUADRO 2 - Período de consumo dos frutos nativos

\begin{tabular}{|l|c|c|c|c|c|c|c|c|c|c|c|c|}
\hline \multirow{2}{*}{ Frutos nativos } & \multicolumn{7}{|c|}{ Meses que estão disponíveis para o consumo } \\
\cline { 2 - 14 } & 01 & 02 & 03 & 04 & 05 & 06 & 07 & 08 & 09 & 10 & 11 & 12 \\
\hline Aboho & & & & & & & & & $\mathrm{X}$ & $\mathrm{X}$ & & \\
\hline Abinõk & & & & & & & & & & & & $\mathrm{X}$ \\
\hline Abinõkza & $\mathrm{X}$ & & & & & & & & & $\mathrm{X}$ & $\mathrm{X}$ & $\mathrm{X}$ \\
\hline Atsik & & & & & & & & $\mathrm{X}$ & $\mathrm{X}$ & & & \\
\hline Awitsunu & $\mathrm{X}$ & & & & & & & & & & $\mathrm{X}$ & $\mathrm{X}$ \\
\hline Bamy & & & & & & & & & & $\mathrm{X}$ & & \\
\hline Hokto & & & $\mathrm{X}$ & $\mathrm{X}$ & & & & & & & & \\
\hline Hoktorire & & $\mathrm{X}$ & & & & & & & & & & \\
\hline Bamyhiri & & & & & & & & & & & $\mathrm{X}$ & $\mathrm{X}$ \\
\hline Bamyekpe & & & & & $\mathrm{X}$ & & & & & & & \\
\hline Tomaze & & $\mathrm{X}$ & $\mathrm{X}$ & & & & & & & & & \\
\hline Maze & & & & & $\mathrm{X}$ & $\mathrm{X}$ & $\mathrm{X}$ & $\mathrm{X}$ & $\mathrm{X}$ & & & \\
\hline Matsaek & & & & & $\mathrm{X}$ & $\mathrm{X}$ & $\mathrm{X}$ & $\mathrm{X}$ & $\mathrm{X}$ & & & \\
\hline Waijak & & & & & & & & $\mathrm{X}$ & $\mathrm{X}$ & & & \\
\hline Pozokyry & & & & & & & $\mathrm{X}$ & $\mathrm{X}$ & & & & \\
\hline Pozokyryza & $\mathrm{X}$ & $\mathrm{X}$ & $\mathrm{X}$ & $\mathrm{X}$ & & & & & & $\mathrm{X}$ & $\mathrm{X}$ & $\mathrm{X}$ \\
\hline Sokorohaek & & & & & & & & & $\mathrm{X}$ & $\mathrm{X}$ & $\mathrm{X}$ & \\
\hline
\end{tabular}




\begin{tabular}{|l|c|c|c|c|c|c|c|c|c|c|c|c|}
\hline Iharahokota & & & & & & & $\mathrm{X}$ & $\mathrm{X}$ & & & & \\
\hline Tsamyekawy & & $\mathrm{X}$ & $\mathrm{X}$ & & & & & & & & & \\
\hline Tometsa & & & & & $\mathrm{X}$ & $\mathrm{X}$ & $\mathrm{X}$ & $\mathrm{X}$ & $\mathrm{X}$ & & & \\
\hline Hahazikhara & $\mathrm{X}$ & & & & & & & & & $\mathrm{X}$ & $\mathrm{X}$ & $\mathrm{X}$ \\
\hline Mazikpinuhã & & & $\mathrm{X}$ & $\mathrm{X}$ & & & & & & & & \\
\hline Zuru & $\mathrm{X}$ & $\mathrm{X}$ & $\mathrm{X}$ & & & & & & & & & $\mathrm{X}$ \\
\hline Watsõetsa & $\mathrm{X}$ & $\mathrm{X}$ & $\mathrm{X}$ & $\mathrm{X}$ & $\mathrm{X}$ & & & & & & & \\
\hline Oktsatatsa & & & & & & & $\mathrm{X}$ & $\mathrm{X}$ & $\mathrm{X}$ & & & \\
\hline Tsawaraktsa & $\mathrm{X}$ & $\mathrm{X}$ & $\mathrm{X}$ & $\mathrm{X}$ & $\mathrm{X}$ & $\mathrm{X}$ & & & & & & \\
\hline Tsaziukzatsa & & & & & & & $\mathrm{X}$ & $\mathrm{X}$ & & & & \\
\hline Oktsoto & & & & & & & & & $\mathrm{X}$ & $\mathrm{X}$ & $\mathrm{X}$ & \\
\hline Peky & $\mathrm{X}$ & $\mathrm{X}$ & $\mathrm{X}$ & & & & & & & & & $\mathrm{X}$ \\
\hline Zuruza & & & & & & & & $\mathrm{X}$ & $\mathrm{X}$ & $\mathrm{X}$ & $\mathrm{X}$ & \\
\hline Pitsi & $\mathrm{X}$ & $\mathrm{X}$ & $\mathrm{X}$ & & & & & & & $\mathrm{X}$ & $\mathrm{X}$ & $\mathrm{X}$ \\
\hline Arabata & & & & & & & & & $\mathrm{X}$ & $\mathrm{X}$ & $\mathrm{X}$ & $\mathrm{X}$ \\
\hline
\end{tabular}

Fonte: Dados coletados na pesquisa.

Outra maneira para determinar o ciclo sazonal seria por meio do nome científico com posterior pesquisa na literatura. Porém, o povo Rikbaktsa tem conhecimentos dos nomes dos frutos da sua região somente em língua materna. Essa foi uma das maiores dificuldades para fazer ciclo sazonal, pois por não saber os nomes na língua portuguesa, foi inviável identificar os nomes científicos dessas espécies vegetais, mesmo comparando com os livros ilustrados de Medeiros (2011) e de Shanley, Serra e Medina (2010).

Frente aos dados apresentados, entende-se que o estudo pode propiciar o fortalecimento da cultura desse povo, especialmente no que se refere ao registro dos saberes tradicionais, como nesse caso envolvendo a alimentação. Conforme defendido por Crepaldi (2012), a maneira com que os indígenas vivem e se relacionam com a natureza poderiam contribuir com o não índio, na medida em que ocorram trocas de saberes e experiências. Cabe lembrar que a autora também acredita que essas ações de registrar aspectos de sua própria cultura contribuem também para o fortalecimento da identidade do índio.

Além do mais, ao estudar os frutos nativos consumidos pelos Rikbaktsa, foi possível estabelecer relações entre elementos da cultura e os aspectos científicos envolventes, o que pode contribuir para o ensino de ciências de indígenas e não indígenas, uma vez que possibilita o diálogo entre esses conhecimentos e torna o estudo envolvente. 
Aos não indígenas, em especial, as contribuições vão além da compreensão de aspéctos estudados em ciências naturais, pois pode proporcionar também a valorização da cultura do outro e o respeito à diversidade. Além disso, corrobora o pensamento de Maturana (1997), que compreende que a educação se constrói o tempo todo e seu processo se estabelece de maneira recítroca na convivência com o outro.

\section{CONSIDERAÇÕES FINAIS}

Esta pesquisa que foi elaborada a partir dos conhecimentos dos anciãos Rikbaktsa e das observações a campo, o que permitiu catalogar trinta e duas espécies de frutos, cada um com seu determinado período de frutificação, sua maneira de preparo e até alguns segredos míticos envolvidos. Constatou-se que alguns servem para comer, assim que retirados do pé, outros são guardados e levam três ou mais dias para amadurecer, outros são cozidos e assim por diante. Suco ou chicha, cozido ou cru, os frutos sempre são bem vindos e se fazem presentes na alimentação do povo desde muitas gerações.

A experiência adquirida ao realizar essa pesquisa permitiu, sobretudo, ao autor indígena, uma grande realização pessoal e também profissional, pois oportunizou conhecer os nomes das frutas na língua materna, além de oportunizar o conhecimento dos frutos que existem na região onde seu povo mora e também em outras terras indígenas do povo Rikbaktsa.

Com a realização desse estudo, é possível concluir que muitos aprendizados foram construídos, tais como os nomes na língua materna, os na língua portuguesa e os nomes científicos dessas espécies vegetais e a descrição do modo de consumo e sazonalidade dos frutos nativos existentes na região em que o povo Rikbaktsa está estabelecido. Em síntese, este tema é de grande importância, pois registra a cultura do povo Rikbaktsa e sua relação com a natureza, além de subsidiar um material que contempla as especificidades locais e os conhecimentos científicos sobre o assunto, para que possam vir a ser explorados em aulas de ciências naturais de indígenas e não indígenas. 
Na certeza de que o estudo nunca estará acabado, fica como sugestões ou provocação para pesquisas futuras, a catalogação sistemática do período de floração, de forma que o não indígena utiliza esses frutos investigandos na literatura, além da composição físico-química dessas frutas.

\section{REFERÊNCIAS}

ANGROSINO, M. Etnografia e observação participante. Porto Alegre: Artmed, 2009. (Coleção pesquisa qualitativa).

ARRUDA, R. S. V. Os Rikbaktsa: Mudança e tradição. Tese (Doutorado em Antropologia). Pontifícia Universidade Católica, São Paulo, 1992.

ARRUDA, R. S. V. Os Rikbaktsa do rio Juruena: a dinâmica da tradição. la.. ed. Saarbrucken, Alemanha: Novas Edições Acadêmicas, 2014.

BEAUD, S.; WEBER, F. Guia para pesquisa de campo: produzir e analisar dados etnográficos. Petrópolis: Vozes, 2007.

CREPALDI, G. B. Alimentação indígena em Mato Grosso: educação ambiental e sustentabilidade entre etnias de estudantes da Faculdade Indígena Intercultural. Dissertação (Mestrado em Ciências Ambientais). Universidade do Estado de Mato Grosso, Cáceres/MT, 2012.

FUNAI. Fundação Nacional do Índio. Levantamento 2010. Disponível em: www.funai.gov.br/mapas/etnia/etn_mt.htm. Acesso em: 13 mai 2015.

GONCALVES, K. G.; DUARTE, G.S.D; TSUKAMOTO FILHO, A. A. Espécies frutíferas do cerrado e seu potencial para os SAFs. Flovet, v. 1, p. 64-78, 2015.

JANUÁRIO, E. R. da S., et al. Culinária Indígena. Barra do Bugres: UNEMAT, 2009.

SHANLEY, P.; SERRA, M.; MEDINA, G. (Org.) Frutíferas e plantas úteis na vida amazônica. /llustradores, Silvia Cordeiro, Miguel Imbira. 2. ed. rev. ampl. Embrapa. Bogor, ID: Cifor, 2010.

MATURANA, H. F. Ontologia da realidade. Belo Horizonte: Editora UFMG, 1997.

MEDEIROS, J. de D. Guia de campo: vegetação do Cerrado 500 espécies. Brasilia: MMA/SBF, 2011.

PEREIRA, A. H. O pensamento mítico do Rikbaktsa. São Leopoldo: Instituto Anchietano de Pesquisas, 1994. 
ISA. Rikbaktsá. Instituto Socioambiental. Site Povos Indígenas no Brasil. IDisponível em: <http://pib.socioambiental.org/pt/povo/rikbaktsa> Acesso em: 02 fev 2016.

REIS, V.; FRANÇA, C. C. Rikbaktsa: Uma História sob duas Perspectivas. Revista Moinhos, v. 1, p. 5-20, 2013.

VIEIRA, et. al. Frutas nativas da região Centro-Oeste. Brasília: Embrapa Recursos Genéticos e Biotecnologia, 2006.

Recebido em: Janeiro de 2018 Aprovado em: Junho de 2018 